\title{
THE PEPITE SCHEME FOR THE PROMOTION OF THE FRENCH STUDENT ENTREPRENEURSHIP: THE PEPITE PACA EST CASE
}

\section{СХЕМА РЕРІТЕ ДЛЯ ПРОДВИЖЕНИЯ ФРАНЦУЗСКОГО СТУДЕНЧЕСКОГО ПРЕДПРИНИМАТЕЛЬСТВА: ДЕЛО РЕРІТЕ РАСА ЕSТ CASE}

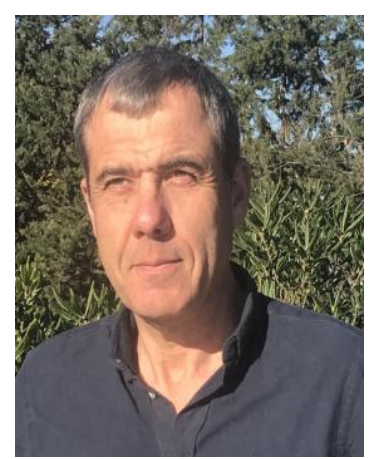

e-mail:

Abstract

Аннотация

Key words

\section{Olivier HUEBER}

associate professor in economics at University Côte d'Azur, vice dean of Nice Institute of Technology in charge of Entrepreneurship and Innovation, full member of the Research Institute GREDEG-CNRS, PhD (Nice, France)

\section{ХУБЕР ОЛивер}

доцент кафедры экономики университета Лазурный Берег, заместитель декана Технологического института Ниццы по предпринимательству и инновациям, действительный член Научно-исследовательского института GREDEG-CNRS, PhD (Ницца, Франция)

olivier.hueber@univ-cotedazur.fr

France has been a pioneer since 2014 in the creation at national level of a new status of student entrepreneur. This status is administered in a decentralized manner by local networks called PEPITE which bring together the main public and private players in the entrepreneurial ecosystem. Nearly six years after the creation of this innovative device for promoting student entrepreneurship, an initial assessment can begin to be done. The objective of this article is to present the originality of the PEPITE system and the status of student entrepreneur with particular attention to a PEPITE called PEPITE PACA EST

Франция с 2014 года является пионером в создании на национальном уровне нового статуса студенческого предпринимателя. Этот статус децентрализованно управляется местными сетями, называемыми PEPITA, которые объединяют основных государственных и частных игроков в предпринимательской экосистеме. Почти через шесть лет после создания этого инновационного механизма для поощрения студенческого предпринимательства может начаться первоначальная оценка. Цель данной статьи - представить оригинальность системы PEРITЕ и статус студента-предпринимателя с особым вниманием к ПЕПИТУ под названием PEPITE PACA EST

student entrepreneurship, student entrepreneurship status, higher education, 
Ключевые слова студенческое предпринимательство, статус

студенческого предпринимательства, высшее образование, РЕРІТЕ

\section{Introduction}

Less than a decade ago, the French educational system devoted to the promotion of the entrepreneurship was characterised mainly by a gap between the French Business Schools («Grandes écoles à la Française») and the public Universities. Numerous actions of promotion very fruitful in term of firm creation were not at all coordinated. A waste of energies and informations had to be deplored. From the year 2009, the French Ministry of Higher Education has set up an extensive network of partnership gathering private and public institution devoted to the promotion of the student entrepreneurship. Such a scheme, initially called «Pôles pour l'Entrepreneuriat Etudiant» (Student poles for Entrepreneurship), was in year 2014 reinforced and renamed PEPITE (Student poles for Innovation, transfer and Entrepreneurship). The French student entrepreneurship scheme widely developed on the entire French territory has specific features that make it unique and, in some way, pioneering (Hueber, 2012).

\section{(i) The French experience of student entrepreneur poles (2009-2014)}

In the last decade, the French higher education system had to catch up in the area of the promotion of student entrepreneurship. The entrepreneurship courses were not widespread in the French education system and very few projects of enterprise creation from student were supported by public universities (Hueber, 2011). Only higher business schools an engineer schools had been able to propose a real teaching program in the area of the Entrepreneurship and an effective accompaniment of projects. Faced with this unflattering observation, the French Ministry of higher education and research decided in 2009 to ask public universities to set up locally large network gathering private and public institutions involved in the promotion of entrepreneurship. From this desire on the part of the French Government were created the same year the first poles of student entrepreneurship. From the beginning, the development dynamic of these poles has been strong. Twenty poles, carried by public universities, were created throughout France. Financially, these poles have received an endowment from the public financial institution namely «Caisse des dépôts». The initial endowment was not really substantial, less than 2 euros per student and per year but sufficient to boost a new dynamic for the promotion of the student entrepreneurship. From the initial public national endowment, many poles were able to raise additional funds from local public authorities or from the private sector (table 1). These seed funds allowed the French Entrepreneurship poles to undertake actions in the areas of the entrepreneurship awareness, the entrepreneurship education, the accompaniment of projects, the hosting of projects in business incubators or in coworking spaces. In the field of student entrepreneurship, it takes a long time between planting and harvesting. The student entrepreneurship poles from year 2009 
Направление 2. Сотрудничество бизнеса и вузов: лучиие европейские практики. Российский и Казахский onbim

to year 2013 provoked an inexorable tidal wave of change in the French University culture.

Table 1 - Budget for the period 2009-2013 of the student entrepreneurship pole Cré@tude ${ }^{1}$

\begin{tabular}{|l|c|}
\hline \multicolumn{1}{|c|}{$2009-2013$} & Assets \\
\hline National endowment (Caisse des dépôts) & $140000 €$ \\
\hline Private sector (tax learning) & $60000 €$ \\
\hline Local endowment (Régional council) & $30000 €$ \\
\hline Total & $230000 €$ \\
\hline Total per student (35 000 students) & $6,6 €$ \\
\hline
\end{tabular}

Source: PEPITE PACA EST

\section{(ii) The national student entrepreneur status}

In year 2014, the promising experiment of the student entrepreneurship poles was reinforced by the creation at the national level of a new Student status called «Student-entrepreneur status». Such a similar status had been introduced previously locally in several public universities in Europe, like for instance in the Belgian University of Liège, but never at a state level. On this issue, the French government decision of creating a national student entrepreneurship status was a world first. The basic idea that has prevailed in the creation of the national student entrepreneur status was that of copying the French national status of high-level sports student. In France, but also in several others national public higher education systems, high-level sports students benefit from a layout of their studies. In the same spirit as that of the highlevel sports student status, the student entrepreneur status also makes it possible to arrange studies in order to set up an entrepreneurial project without jeopardizing the chances of success in studies. Like all higher French education courses, to apply for the national student entrepreneur status, a candidate must hold a French baccalaureate or equivalent (French or foreign).

Such a national student entrepreneur status framework provides to all student entrepreneurs the following benefits:

- The right to enroll in a dedicated student entrepreneur diploma

- Support by experts in entrepreneurial project accompaniment

- Housing of the Entrepreneurial project in a nursery, an incubator or a coworking area

- Possibility of replacing the usual company internship with an entrepreneurial scenario

Any holder of a French baccalaureate can choose to only apply for the national student entrepreneur status and enroll in a French university only for a dedicated student entrepreneur diploma. Nevertheless, even if it is possible, it is not the spirit of the status. This status has been for students who are pursuing their studies while

\footnotetext{
${ }^{1}$ The student entrepreneurship pole Cré@tude, hold by the University of Nice - Sophia Antipolis had been in charge from the year 2009 to the year 2003 of the promotion of the student entrepreneurship in the two French departments of the French Riviera (Alpes Maritimes and Var).
} 
working on their entrepreneurial project. It is the double graduation that is favored namely, a degree in initial studies and a student entrepreneur degree.

Since its creation in 2014, the student entrepreneur status has attracted interest from students and graduates of higher education. This interest has grown continuously (table 2).

Table 2 - Number of student entrepreneurs at the national level

\begin{tabular}{|c|c|c|c|c|}
\hline Indicator & 2014-2015 & $2015-2016$ & $2016-2017$ & 2017-2018 \\
\hline $\begin{array}{l}\begin{array}{l}\text { Number of holders of the French studen } \\
\text { entrepreneur status }\end{array} \\
\end{array}$ & 637 & 1471 & 2689 & 3652 \\
\hline Growth rate in \% & & 131 & 83 & 36 \\
\hline
\end{tabular}

The share of women with the status of student entrepreneur in France is $30 \%$ but this share continues to grow since the creation of the status. Foreigners studying in France are also interested in the status. 13\% of holders of student entrepreneur status are foreigners. More than half of the student entrepreneurs (53\%) set up an entrepreneurial team project. This means that many student entrepreneurs often work on the same entrepreneurial project.

\section{(iii) The PEPITE network (from 2014 to the present)}

In parallel with the creation of the national status of student entrepreneur, the French Ministry of Higher Education has created 29 Student poles for Innovation, transfer and Entrepreneurship called PEPITE. In most cases, PEPITE (s) have taken over from the pre-existing poles of student entrepreneurship of the period 2009-2014.

Each of the 29 PEPITE is individually in charge of the administration of the student entrepreneur status on its territory. Each PEPITE receives of a go with the flow, from a national online platform, the applications of students from its territory (Bousquet, F., Barbat, V., Verstraete, 2016). Several times a year the PEPITE empanels a jury for evaluating each application for the status. Such an Approval Committee is made up of teachers in Entrepreneurship, of professionals of project support, of a representative of the Ministry of Research and Higher Education, of a responsible for hosting projects (in a nursery or an incubator). Each PEPITE has the freedom to set its own evaluation criteria. However, the national coordination of PEPITE, which brings together the network of 29 PEPITES, offers evaluation grids.

For instance, the PEPITE PACA EST which is in charge of the status for the two departments of Alpes-Maritimes and Var set up the following four criteria:

- Market dimension

- Finance dimension

- Maturity of the project

- Team's cohesion (if a same project concerns several applicants)

Each member of the Approval Committee gives a mark for each criterion (from 1 to 5) and a tabulation of all the data permits a grading. The classification is then submitted for approval and conformity check of the selection procedure to the representative of the Regional Delegation for Research and Technology (DRRT). Once approved by the DRRT, the PEPITE sends its final decision to the Ministry of 
Направление 2. Сотрудничество бизнеса и вузов: лучиие европейские практики. Российский и Казахский onblm

Education and Research, which issues the national status Student Entrepreneur to the admitted students. The Ministry never intervene in the choice of a PEPITE but officially grants the Student Entrepreneur status because it is a national status. The Student Entrepreneur status is granted for only one academic year. However, if the entrepreneurial project requires several years, it is possible for a PEPITE to renew the status to a student.

The student entrepreneurs' profiles are very diversified. Some are undergraduate (Bachelor or Licence) others are post graduated (Master or $\mathrm{PhD}$ ). Some of them have knowledge in management, in Law or in accounting and others do not. Some of them really want to come up with a business creation in the end of their studies and others consider the status only as a great rewarding experience which improve their curriculum vitae. Facing to such a diversity of profiles, the PEPITE has to provide to each of its Student entrepreneur a kind of a pedagogic contract which can be compared to an Erasmus Pedagogic contract applied to an entrepreneurial project.

The pedagogic contract dedicated to a student entrepreneur specifies the following:

- Entrepreneurial knowledge to be acquired in higher education (Business Plan, Business law, Strategic Management, Marketing and so forth) coworking area)

- The housing place of the entrepreneurial project (Incubator, nursery,

- The name of the support professional of the student

- The arrangements for adjusting studies in case of a double degree course (Student Entrepreneur diploma and another one)

The entrepreneurial knowledge to be acquired by the owner of the Student Entrepreneur status can be acquired through the Student Entrepreneur Diploma. Each of the 29 PEPITE set up a Student Entrepreneur Diploma among its Universities. For instance, the PEPITE PACA EST allows students with the status to register in the Student Entrepreneur Diploma either in the University of Toulon either in the University Côte d'Azur. These two universities belonging to the same PEPITE adopted the same degree program for this student entrepreneur diploma. The choice of the housing place of the entrepreneurial project relies on the characteristics of the entrepreneurial project. The PEPITE PACA EST closed agreements with most of the incubator, nursery or coworking area located in its administrative territory. Each of them has its specificities and key areas of focus (table 3). On the strength of its first experience of student entrepreneur poles (2009-2014), the PEPITE PACA EST has managed to unite on all its territory the main public and private institutions engaged in the promotion of entrepreneurship (annex. 1).

The Organizational diagram of the student entrepreneur path is organized so the bearer of the entrepreneurial project - with or without the student Entrepreneur status - is always feel attended personally (Graph. 1). In addition, if the maturation of the project requires times, the Approval Committee of the PEPITE can still allow the student to keep his status over several years. 
Table 3 - Hosting place of entrepreneurial projects from students of the PEPITE PACA EST

\begin{tabular}{|l|l|l|l|}
\hline \multicolumn{1}{|c|}{ Sector/Area of activity } & Incubator/nursery/coworking space & \multicolumn{1}{|c|}{ Location } & \multicolumn{1}{|c|}{ Department } \\
\hline Chemistry, fragance, aromas & Pôle Azur Provence & Grasse & Alpes Maritimes \\
\hline $\begin{array}{l}\text { Smarcities, mobiliy, city } \\
\text { infrastructures }\end{array}$ & $\begin{array}{l}\text { Nice Métropole (CEEI), Toulon } \\
\text { Var Technologies (TVT) }\end{array}$ & Nice, Toulon & Alpes Maritimes and Var \\
\hline $\begin{array}{l}\text { film industry, publishing sector, } \\
\text { video game industry, tourism }\end{array}$ & CréaCannes & Cannes & Alpes Maritimes \\
\hline $\begin{array}{l}\text { high technology sector } \\
\text { (computing, electronics, } \\
\text { robotics...) }\end{array}$ & $\begin{array}{l}\text { Incubateur PACA EST, Toulon } \\
\text { Var Technologies, Telecom } \\
\text { ParisTech }\end{array}$ & $\begin{array}{l}\text { Nice, Toulon, } \\
\text { Sophia Antipolis }\end{array}$ & Alpes Maritimes and Var \\
\hline Art linked to Industry & L'E.CO.LE & Carros & Alpes Maritimes \\
\hline Craft production & Créactive06 Cannet & Alpes Maritimes \\
\hline Various sectors & $\begin{array}{l}\text { Edhec Business Center, Skemas } \\
\text { Business center, Kedge Business } \\
\text { School }\end{array}$ & $\begin{array}{l}\text { Nice, Sophia } \\
\text { Antipolis, } \\
\text { Toulon }\end{array}$ & Alpes Maritimes and Var \\
\hline
\end{tabular}

Graph 1: Organizational diagram of the student entrepreneur path

The ministry of higher education and Research, through its financial institution «Caisse des Dépôts», allows an annual grant based on the numbers of students to each PEPITE. Such a capital endowment may vary from year to year. For instance, the PEPITE PACA EST receives roughly 12000 euros per year for approximatively 40 thousand students located on its intervention area.

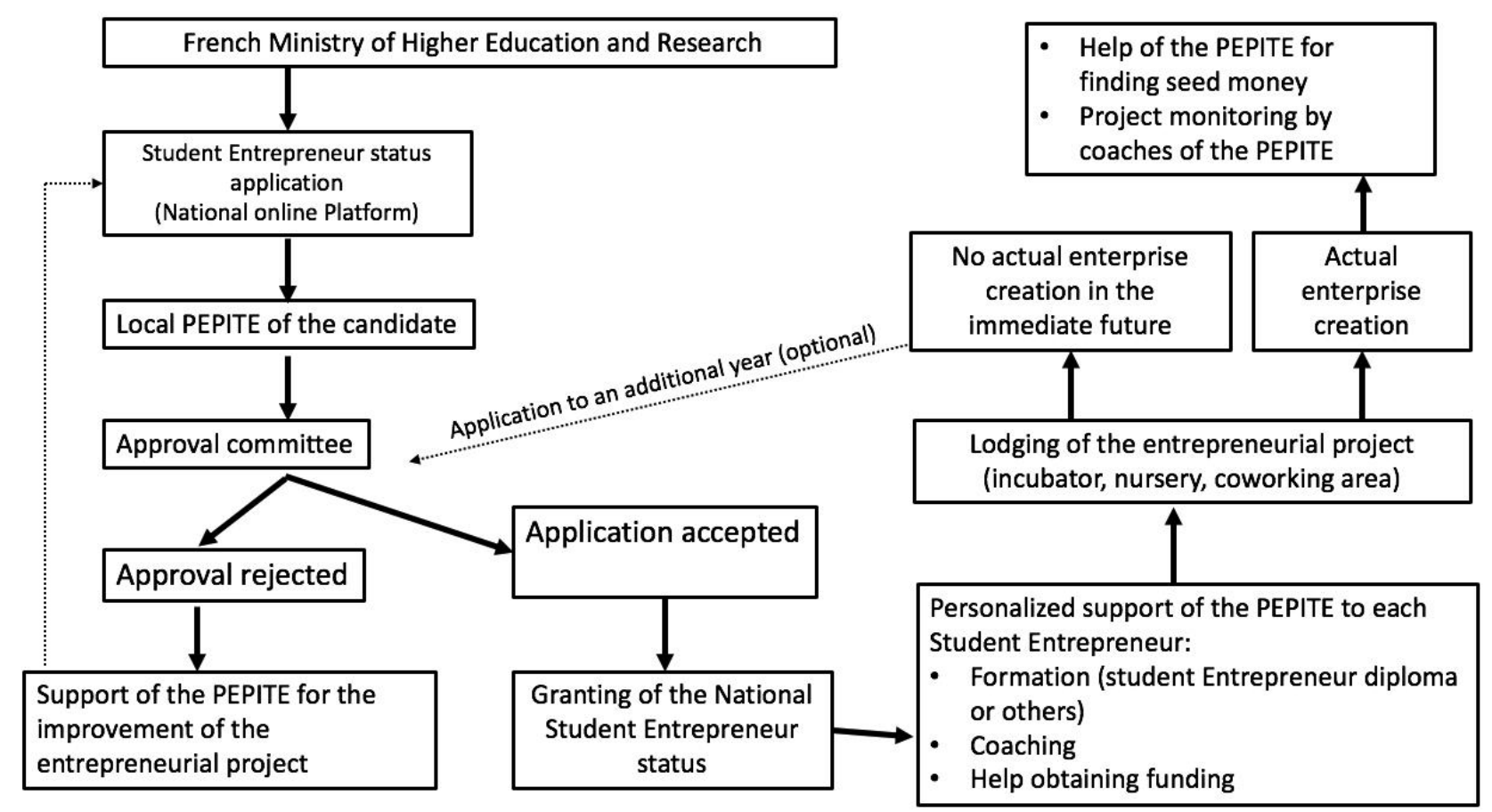

These states funds are complemented by private funds and public funds from the regional administration (Table 4). 
Направление 2. Сотрудничество бизнеса и вузов: лучиие европейские практики. Российский и Казахский onblm

Table 4 - Annual Budget of the PEPITE PACA EST for the university Year 2017-2018 (approx.)

\begin{tabular}{|l|c|}
\hline \multicolumn{1}{|c|}{$2017-2018$} & Assets \\
\hline National endowment (Caisse des dépôts) & $12000 €$ \\
\hline Private sector (tax learning) & $10000 €$ \\
\hline $\begin{array}{l}\text { National endowment (Caisse des dépôts) for the organization of the annual PEPITE } \\
\text { entrepreneurship contest }\end{array}$ & $8000 €$ \\
\hline Local endowment (Regional council) & $30000 €$ \\
\hline Student Entrepreneur tuition fees (on average 300€ per student) & $7000 €$ \\
\hline $\begin{array}{l}\text { Capital contributions from the Universities and institutional members of the PEPITE PACA EST } \\
\text { (wages, premises, consumables) }\end{array}$ & $70000 €$ \\
\hline Total & $137000 €$ \\
\hline Total per Student Entrepreneur (approx. 250) & $548 €$ \\
\hline
\end{tabular}

With an annual budget fluctuating between 100000 and 150000 euros depending on the year, the PEPITE PACA EST finances accompaniments of entrepreneurship projects by professionals and finances actions of promotion of the student entrepreneurship (information, awareness, formation).

\section{Conclusion}

The PEPITE scheme, all over the French territory including the overseas French territories, after a start-up phase is now experiencing its take-off phase. There is an increase of 30\% of the student entrepreneurs in France each year. In year 2018, France had close to 3,600 students and we can expect a staff of more than 10,000 student entrepreneurs in year 2022. All these student entrepreneurs are not necessarily going to really create their activity, but their large numbers will participate in spreading the entrepreneurial spirit in the French economy. People evaluate too often a device devoted to promote entrepreneurship by focusing on the actual number of business creation. It is a mistake to reason in this way. It can take a very long time between raising a person's awareness to entrepreneurship and the moment that person goes to the real act of creation. Today, only 5\% of student entrepreneurs from the PEPITE PACA EST start their business in the year following their studies but for the remaining 95\%, some of them will create much later and others will keep in their job as an employee the entrepreneurial spirit, which will be beneficial for their employers. Several countries are watching today the French PEPITE device closely to duplicate it at home. This is the case for Tunisia and Morocco, both of which have signed an agreement with the PEPITE network via the SALEEM project (Structuring and Supporting Student Entrepreneurship in the Maghreb).

Annex 1 - The PEPITE PACA EST' network

\begin{tabular}{|l|r|l|l|}
\hline \multicolumn{1}{|c|}{ Role } & Location* & \multicolumn{2}{c|}{ Institution } \\
Project Manager & 06 & $\begin{array}{l}\text { Université de Nice - Sophia } \\
\text { Antipolis }\end{array}$ & University \\
\hline Leading partner & 83 & Université du Sud Toulon Var & University \\
\hline Leading partner & 06 & SKEMA & Business School \\
\hline Leading partner & 06 & EDHEC & Business School \\
\hline Leading partner & 83 & Incubateur PACA EST & Incubator \\
\hline
\end{tabular}


INTERNATIONAL DISSEMINATION CONFERENCE ENINEDU

March 24-25, 2020, Orel State University, Orel, Russia

\begin{tabular}{|l|r|l|l|} 
Leading partner & 83 and 06 & Telecom ParisTech & Incubator \\
\hline Leading partner & 06 & Telecom Valley & Association \\
\hline Leading partner & 83 & Toulon Var Technologie & Association \\
\hline Contact Partner & 06 & Union pour l'Entreprise 06 & Employer Union \\
\hline Contact Partner & 83 & Union Patronale du Var & Employer Union \\
\hline Contact Partner & 83 & CCI Var & Chamber of Commerce \\
\hline Contact Partner & 06 & Chambre des Métiers 06 & Trades house \\
\hline Contact Partner & 83 & Chambre des métiers du var & Trades house \\
\hline Contact Partner & 06 & CJDE 06 & Employer Union \\
\hline Contact Partner & 83 & CJDE83 & Employer Union \\
\hline Contact Partner & 06 & UNAPL 06 & Association \\
\hline Contact Partner & 83 & Interface 83 & Incubator \\
\hline Contact Partner & 06 & Sophia Business Angels & Network of Business angels \\
\hline Contact Partner & 06 & Antipolis Innovation Campus & $\begin{array}{l}\text { Centre for Enterprise and } \\
\text { Innovation Research }\end{array}$ \\
\hline Contact Partner & 83 and 06 & INPI & $\begin{array}{l}\text { National Institute of Industrial } \\
\text { Property }\end{array}$ \\
\hline Contact Partner & 83 and 06 & PACA entreprendre & Association \\
\hline
\end{tabular}

* The number 83 indicates the Department of the Var and the number 06 indicates the Department of the Alpes Maritimes. Var and Alpes Maritimes gathered are usually called French Riviera.

\section{References}

1. Bousquet, F., Barbat, V., Verstraete, T. (2016), «Influence des préférences de l'entrepreneur sur la dynamique de l'ancrage territorial», Gestion 2000, numéro spécial « Dynamiques territoriales «, mars-avril/mai-juin, p. 53-74.

2. Brenet P., Schieb-Bienfait N., Authier J., (2017) «Concevoir un référentiel de compétences pour les étudiants entrepreneurs: la démarche PEPITE», Entreprendre\&Innover, Graine d'entrepreneurs, vol. 2 (33), pp 29-43

3. Boissin, J.-P., Fayolle, A., \& Messeghem, K. (2012). Renforcer notre conception collective de la connaissance entrepreneuriale. Revue de l'Entrepreneuriat (Editorial), 11(2), 7-9.

4. Boissin, J.P., Branchet, B., Emin, S. and Herbert, J.I. (2009). Students and entrepreneurship: a comparative study of France and the United States. Journal of Small Business \& Entrepreneurship, 22(2):101-122.

5. Hueber, O. (2012) «Innovation poles and innovative entrepreneurship», Marina Dabić University of Zagreb Faculty of Economics and Business, ISBN 978-953-6025-58-9

6. Hueber, O. (2011) «Entrepreneurial education in France», European Commission Marina Dabic, Maciej Pietrzykowski, ISBN 978-83-62662-54-8

7. Loyda Gomez Santos, (2014). L'enseignement de l'entrepreneuriat au sein de l'Université : la contribution de la méthode des cas. Gestion et management. Université de Lorraine, 2014. Français. <NNT : 2014LORR0125>. <tel-01750936> 